\title{
Sickness absence and ventilatory capacity of workers exposed to sulphuric acid mist
}

\author{
M. K. WILLIAMS \\ TUC Centenary Institute of Occupational Health, London School of Hygiene and Tropical \\ Medicine, Keppel Street, London, W.C.1
}

\begin{abstract}
Williams, M. K. (1970). Brit. J. industr. Med., 27, 61-66. Sickness absence and ventilatory capacity of workers exposed to sulphuric acid mist. The certified sickness absence and ventilatory capacity of men exposed to high concentrations of sulphuric acid mist in the Forming department of an electric accumulator factory, and in control departments, were investigated. The Forming men showed a slight excess of spells of respiratory disease, particularly bronchitis, but not of other disease. The excess of respiratory disease was due to an increased number of spells in men attacked rather than to an increase in the proportion of men attacked. The absence of a marked excess of lower respiratory tract disease might be due to large mist particle size.

The forced expiratory volume over one second (F.E.V.1.0) and the forced vital capacity (F.V.C.) were measured in Forming men and in a control group at the beginning and end of the afternoon shifts on a Monday and Friday. Statistically significant decreases of both tests on both days could be attributed to circadian variation. Differences between the Forming and control departments in the mean changes of F.E.V.1.0 and F.V.C. during the shift were not significant.
\end{abstract}

The possibility that sulphuric acid mist may be a factor in the excessive mortality associated with smog (polluted fog) has led to extensive animal and environmental investigations (Amdur, 1961). In man, brief exposure to sulphuric acid mist decreases the depth and increases the rate of respiration (Amdur, Silverman, and Drinker, 1952) and causes irritation of the eyes, nose, and throat. Massive exposure has been associated with pulmonary fibrosis, bronchiectasis, and emphysema (Goldman and Hill, 1953) and possibly with death from oedema or spasm of the larynx (Haggard, 1924). After they had repeatedly exposed themselves to sulphur dioxide and sulphuric acid mist Sim and Pattle (1957) became 'sensitized'; subsequent exposure to sulphuric acid mist was followed by cough and wheezing which lasted for months.

Few studies of long-term human exposure to sulphuric acid mist have been made. Malcolm and Paul (1961) showed that men exposed to high con- centrations of sulphuric acid mist in the Forming department of an electric accumulator factory in Lancashire may develop dental erosion with complete loss of the crowns of the incisor teeth. Dental erosion in Forming workers was also found by Ten Bruggen Cate (1968).

An investigation has been made of the certified sickness absence, and ventilatory capacity, of men exposed to sulphuric acid mist in the Forming department described by Malcolm and Paul (1961), and of men in other departments of the same factory serving as controls

\section{Material}

The departments

In the investigation of sickness absence, the Assembly department was chosen as a control department because it contained the largest number of men (Table 4). But because job selection might influence physique and hence sickness absence, the Pasting department was also chosen 
as a control because the kind of work was more comparable with that in the Forming department.

In the investigation of ventilatory capacity, the Plate Cutting department was thought to be as suitable a control department as Assembly or Pasting and was chosen for administrative reasons.

Working conditions

Working conditions are summarized in Table 1.

The Forming department was unheated, with wet floors and open jack-roof ventilation which allowed the acid mist to escape and outside air to enter. The men wore rubber boots and aprons, and surplus Army clothing which became rotted by the acid. They loaded pasted plates into racks in tanks and burnt a lead strip on to the lugs.

TABLE 1

Working Conditions of Departments

\begin{tabular}{|c|c|c|c|c|}
\hline Department & $\underset{\text { mist }}{\mathrm{H}_{2} \mathrm{SO}_{4}}$ & Heating & Floors & $\begin{array}{c}\text { Physical } \\
\text { work } \\
\text { load }\end{array}$ \\
\hline Forming $\quad$. & Present & Nil & Wet & $\begin{array}{l}\text { Moderately } \\
\text { heavy }\end{array}$ \\
\hline Assembly .. & Absent & Good & Dry & Light \\
\hline Pasting $\quad$. & Absent & Good & Wet & $\begin{array}{l}\text { Moderately } \\
\text { heavy }\end{array}$ \\
\hline Plate cutting & Absent & Good & Wet & $\begin{array}{l}\text { Moderately } \\
\text { heavy }\end{array}$ \\
\hline
\end{tabular}

The Assembly department was dry and well heated. The men wore cotton overalls. They assembled plates and separators into boxes to make the finished battery.

The Pasting and Plate Cutting departments had wet floors but were well heated. The men wore rubber boots and aprons over cotton overalls. Pasting men pressed lead oxide paste into the meshes of lead grids by hand or machine. Plate Cutting men cut and cleaned formed plates. The work was judged to be moderately heavy in all departments except Assembly, where it was light.

\section{Methods}

Sickness absence

The sickness absence records of two groups of men were analysed. One group, 'workers', comprised all the men who were still employed in the Forming, Assembly, and Pasting departments on December 31, 1962. Their sickness absence between 1950 and 1962 inclusive was investigated.

The second group, 'ex-workers', comprised all the men who had left the Forming or Assembly departments between 1955 and 1962 inclusive. Their sickness absence between January 1, 1955 and the date of leaving was investigated. (No records prior to these dates were available. Pasting 'ex-workers' were not included because their numbers were small.)

The length of exposure to sulphuric acid mist of both the 'workers' and 'ex-workers' in Forming varied from a few days to more than 40 years.

For all spells of certified absence attributed to sickness, the diagnosis entered by the general practitioner on the first National Insurance Medical Certificate was extracted from the Personnel records and assigned to one of six classes. The classes, and the International Classification of Diseases (World Health Organization, 1967) code numbers of the diagnoses, were as follows:

Class
I Influenza
II Other upper respiratory
tract infection
III Bronchitis
IV Other lower respiratory
tract infection
V Injury
VI Other illness

I.C.D. No.

471

$034,460,462,463,464$, 501,503 $466,490,491$

$464,471,481,484,511$, 514

N844, N845

$011,471,472,473,474$, 493, 717.9, 724.1, 725, 731, 783.7, 788.8, 788.9, N846, N847.9, N848

There is some overlap, e.g., 464 occurs in class II (laryngitis) and class IV (tracheitis).

The diagnosis from the first National Insurance Medical Certificate, although possibly less accurate than a subsequent one, was taken to ensure that the diagnosis used was that of the primary disease rather than of a complication.

The date of birth, the dates of entering and leaving employment, and the date of the beginning of each sickness absence spell were extracted from the records. For the men in each department, both 'workers' and 'exworkers', the number of man-years at risk, and the number of observed spells of absence in each disease class, were determined for each of the nine five-year age groups between 20 and $65(20-24,25-29, \ldots$ 60-64). In any year, men entering employment after June, or leaving employment before July, were counted as half a manyear; entry before July, or- leaving after June, was counted as one man-year. For each class of disease the expected number of spells of absence in each five-year age group in each department in both 'workers' and 'exworkers' was calculated by applying proportionally to the number of man-years the rate of all men combined in that age group.

The numbers of observed and expected spells in each five-year age group were then summed to obtain the numbers in younger (20-34 years) and older (35-64 years) men. The total number of men and the number of men having one or more spells of respiratory disease (classes I, II, III and IV combined) in each department and group were determined subsequently.

\section{Ventilatory capacity}

All men on the 2 p.m.-10 p.m. shift in the Forming and Plate Cutting departments were asked to attend the Medical department before starting work and at the end of the shift on the first day (Monday) and the last day (Friday) of one working week. Measurements of the forced expiratory volume over one second (F.E.V.1.0) and the forced vital capacity (F.V.C.) of each man were made throughout by one of three observers with a Gaenslertype spirometer (McKerrow, McDermott, and Gilson, 
1960). Five blows were made for readings of F.E.V.1.0 and then two blows for F.V.C. The F.E.V.1.0 was calculated as the mean of the last three readings, and the F.V.C. as the mean of the two readings.

\section{Results}

\section{Sickness absence}

Table 2 shows the number of man-years at risk in younger (20-34 years) and older (35-64 years) men in each group and department.

Table 3 shows observed and expected spells of sickness absence in younger and older men for each class of disease, for all respiratory disease, and for all diseases combined. Because of the variation in the number of spells of sickness absence contributed by different individuals, no tests of statistical significance were made. For all respiratory disease both younger and older Forming 'workers' and 'exworkers' have more spells than expected, and Assembly 'workers' have fewer. Bronchitis (class III) and, to a lesser extent, the other respiratory diseases (classes I, II, and III) show a broadly similar pattern.

But in class VI (all other diseases) Forming 'workers' have fewer spells than expected for all ages combined, as do Assembly 'workers'.

'Ex-workers' from Forming, and to a lesser extent from Assembly, show more observed spells than expected in both older and younger men in the majority of disease classes.

The excess of respiratory disease spells in Forming could result from a greater proportion of men attacked or from a larger number of spells in attacked men. For each department and group the total number of men, the number of men having one or more spells of respiratory disease (men attacked), and the number of spells of respiratory disease were calculated. The results are shown in Table 4 together with the number of man-years, the period prevalence of respiratory sickness absence calculated as the number of men attacked per 100 man-years, and the mean attack rate of respiratory disease, calculated as the number of spells per man-year. The number of spells of all diseases combined, and the number of these spells per man-year are also shown in Table 4.
It can be seen that the increased attack rate of respiratory disease in Forming 'workers' is not accompanied by a commensurate increase in period prevalence. The difference in period prevalence between the 'workers' in Forming and Pasting is not significant.

These results suggest that the increased number of spells of respiratory disease in men exposed to sulphuric acid mist was accounted for by an increased incidence of spells in attacked men and not by an increased proportion of men attacked.

\section{Ventilatory capacity}

Complete sets of readings were obtained from 29 of the 31 Forming men and from 16 of the 17 Plate Cutting controls. Of the remaining three men, the F.V.C. of two exceeded the capacity of the spirometer and the third man was absent on one day. The incomplete sets of readings were excluded from the results.

In neither department did the overall F.E.V. $\cdot_{\cdot \cdot \cdot 0}$ or F.V.C. at the beginning of the Monday shift differ significantly from those on the Friday.

In both departments there were decreases in mean F.E.V.1.0 and mean F.V.C. during both shifts. In Forming, the decreases in both tests were statistically significant on both days. In Plate Cutting only the decrease in F.E.V.1.0 on the Friday was significant (Table 5).

The mean changes in F.E.V.1.0 and F.V.C. on the Monday shift did not differ significantly from those on Friday in either department.

On neither day were the mean changes in F.E.V.1.0 and F.V.C. in the Forming department significantly different from those in Plate Cutting.

\section{Discussion}

Concentration and particle size of the sulphuric acid mist

In this Forming department Anfield and Warner (1968 and personal communication) found a mean concentration of $1.4 \mathrm{mg}$. $\mathrm{H}_{2} \mathrm{SO}_{4} / \mathrm{m}^{3}$ (ranging from a trace to $6.1 \mathrm{mg} . / \mathrm{m}^{3}$ ) from 38 observations made on two days; Malcolm and Paul (1961) found that concentrations varied from 3.0 to $16.6 \mathrm{mg} . / \mathrm{m}^{3}$ on

TABLE 2

Number of Man-years at Risk of Younger and Older Men

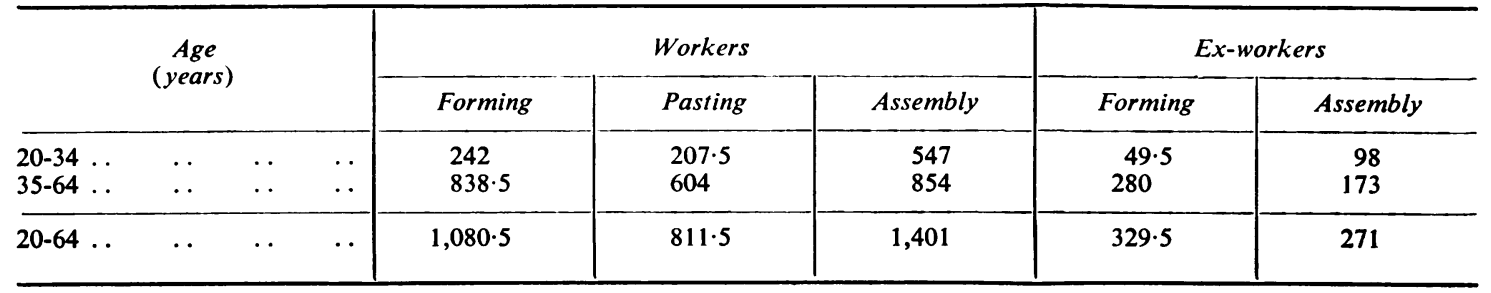


TABLE 3

Observed (O) and Expected (E) Spells of Sickness Absence based on the Overall Rate in Each of Nine Five-year Age Groups, by Disease Class, Age Range, Group AND DEPARTMENT

\begin{tabular}{|c|c|c|c|c|c|c|c|c|c|c|c|c|c|c|}
\hline \multirow{2}{*}{\multicolumn{3}{|c|}{$\begin{array}{c}\text { Disease } \\
\text { class }\end{array}$}} & & \multirow{2}{*}{$\begin{array}{c}\text { Age } \\
\text { range }\end{array}$} & \multicolumn{6}{|c|}{ Workers } & \multicolumn{4}{|c|}{ Ex-workers } \\
\hline & & & & & \multicolumn{2}{|c|}{$\begin{array}{l}\text { Forming } \\
O \quad E\end{array}$} & \multicolumn{2}{|c|}{$O_{E}^{\text {Pasting }}$} & \multicolumn{2}{|c|}{$\begin{array}{l}\text { Assembly } \\
O \quad E\end{array}$} & \multicolumn{2}{|c|}{$\begin{array}{l}\text { Forming } \\
O \quad E\end{array}$} & \multicolumn{2}{|c|}{$\begin{array}{l}\text { Assembly } \\
O\end{array}$} \\
\hline \multirow[t]{2}{*}{$\begin{array}{l}\text { I } \\
\text { Influenza }\end{array}$} & \multirow[t]{2}{*}{$\begin{array}{l}. . \\
\ldots\end{array}$} & \multirow[t]{2}{*}{$\begin{array}{l}\cdots \\
\cdots\end{array}$} & \multirow[t]{2}{*}{$\begin{array}{l}\ldots \\
\ldots\end{array}$} & $\begin{array}{l}20-34 \\
35-64\end{array}$ & $\begin{array}{l}27 \\
59\end{array}$ & $\begin{array}{l}16 \\
55\end{array}$ & $\begin{array}{l}11 \\
38\end{array}$ & $\begin{array}{l}14 \\
40\end{array}$ & $\begin{array}{l}27 \\
56\end{array}$ & $\begin{array}{l}37 \\
59\end{array}$ & $\begin{array}{r}4 \\
15\end{array}$ & $\begin{array}{r}3 \\
17\end{array}$ & $\begin{array}{r}9 \\
14\end{array}$ & $\begin{array}{r}7 \\
11\end{array}$ \\
\hline & & & & $20-64$ & 86 & 71 & 49 & 54 & 83 & 96 & 19 & 20 & 23 & 18 \\
\hline \multirow{2}{*}{\multicolumn{3}{|c|}{$\begin{array}{l}\text { II } \ldots \quad \ldots \\
\text { Other upper respiratory } \\
\text { tract disease }\end{array}$}} & \multirow[t]{2}{*}{. } & $\begin{array}{l}20-34 \\
35-64\end{array}$ & $\begin{array}{l}26 \\
40\end{array}$ & $\begin{array}{l}20 \\
38\end{array}$ & $\begin{array}{l}20 \\
17\end{array}$ & $\begin{array}{l}17 \\
27\end{array}$ & $\begin{array}{l}34 \\
42\end{array}$ & $\begin{array}{l}45 \\
41\end{array}$ & $\begin{array}{r}5 \\
23\end{array}$ & $\begin{array}{r}4 \\
12\end{array}$ & $\begin{array}{r}10 \\
3\end{array}$ & $\begin{array}{l}9 \\
7\end{array}$ \\
\hline & & & & $20-64$ & 66 & 58 & 37 & 44 & 76 & 86 & 28 & 16 & 13 & 16 \\
\hline \multirow[t]{2}{*}{$\begin{array}{l}\text { III . . } \\
\text { Bronchitis }\end{array}$} & \multirow[t]{2}{*}{$\begin{array}{l}\cdots \\
\cdots\end{array}$} & \multirow[t]{2}{*}{$\begin{array}{l}\cdots \\
\cdots\end{array}$} & \multirow[t]{2}{*}{$\begin{array}{l}\ldots \\
\ldots\end{array}$} & $\begin{array}{l}20-34 \\
35-64\end{array}$ & $\begin{array}{l}10 \\
53\end{array}$ & $\begin{array}{r}5 \\
44\end{array}$ & $\begin{array}{r}5 \\
32\end{array}$ & $\begin{array}{r}5 \\
32\end{array}$ & $\begin{array}{r}6 \\
29\end{array}$ & $\begin{array}{l}12 \\
41\end{array}$ & $\begin{array}{r}4 \\
19\end{array}$ & $\begin{array}{r}1 \\
17\end{array}$ & $\begin{array}{r}1 \\
11\end{array}$ & $\begin{array}{r}2 \\
10\end{array}$ \\
\hline & & & & $20-64$ & 63 & 49 & 37 & 37 & 35 & 53 & 23 & 18 & 12 & 12 \\
\hline \multirow{2}{*}{\multicolumn{3}{|c|}{$\begin{array}{l}\text { IV } \cdots \\
\text { Other lower respiratory } \\
\text { tract disease }\end{array}$}} & \multirow[t]{2}{*}{. } & $\begin{array}{l}20-34 \\
35-64\end{array}$ & $\begin{array}{l}4 \\
8\end{array}$ & $\begin{array}{l}2 \\
8\end{array}$ & $\begin{array}{l}2 \\
6\end{array}$ & $\begin{array}{l}2 \\
6\end{array}$ & $\begin{array}{r}2 \\
10\end{array}$ & $\begin{array}{l}5 \\
8\end{array}$ & $\begin{array}{l}1 \\
2\end{array}$ & $\begin{array}{l}\mathbf{0} \\
3\end{array}$ & $\begin{array}{l}1 \\
0\end{array}$ & $\begin{array}{l}1 \\
1\end{array}$ \\
\hline & & & & $20-64$ & 12 & 10 & 8 & 8 & 12 & 13 & 3 & 3 & 1 & 2 \\
\hline \multirow{2}{*}{\multicolumn{3}{|c|}{ All respiratory disease }} & \multirow[t]{2}{*}{. } & $\begin{array}{l}20-34 \\
35-64\end{array}$ & $\begin{array}{r}67 \\
160\end{array}$ & $\begin{array}{r}43 \\
145\end{array}$ & $\begin{array}{l}38 \\
93\end{array}$ & $\begin{array}{r}38 \\
105\end{array}$ & $\begin{array}{r}69 \\
137\end{array}$ & $\begin{array}{r}99 \\
149\end{array}$ & $\begin{array}{l}14 \\
59\end{array}$ & $\begin{array}{r}8 \\
49\end{array}$ & $\begin{array}{l}21 \\
28\end{array}$ & $\begin{array}{l}19 \\
29\end{array}$ \\
\hline & & & & $20-64$ & 227 & 188 & 131 & 143 & 206 & 248 & 73 & 57 & 49 & 48 \\
\hline \multirow[t]{2}{*}{$\begin{array}{l}\text { Injury } \\
\text {.. }\end{array}$} & \multirow[t]{2}{*}{$\begin{array}{l}. \\
.\end{array}$} & \multirow[t]{2}{*}{$\begin{array}{l}\cdots \\
\cdots\end{array}$} & \multirow[t]{2}{*}{$\begin{array}{l}. \\
\cdots\end{array}$} & $\begin{array}{l}20-34 \\
35-64\end{array}$ & $\begin{array}{l}10 \\
18\end{array}$ & $\begin{array}{r}9 \\
21\end{array}$ & $\begin{array}{r}5 \\
21\end{array}$ & $\begin{array}{r}8 \\
15\end{array}$ & $\begin{array}{l}18 \\
20\end{array}$ & $\begin{array}{l}20 \\
21\end{array}$ & $\begin{array}{l}4 \\
7\end{array}$ & $\begin{array}{l}2 \\
7\end{array}$ & $\begin{array}{l}6 \\
2\end{array}$ & $\begin{array}{l}4 \\
4\end{array}$ \\
\hline & & & & $20-64$ & 28 & 30 & 26 & 23 & 38 & 41 & 11 & 9 & 8 & 8 \\
\hline \multirow[t]{2}{*}{$\begin{array}{l}\text { VI } \ldots \\
\text { All other }\end{array}$} & \multirow[t]{2}{*}{$\begin{array}{l}. \\
\cdots\end{array}$} & \multirow[t]{2}{*}{$\begin{array}{l}\cdots \\
\cdots\end{array}$} & \multirow[t]{2}{*}{$\begin{array}{l}\cdots \\
\cdots\end{array}$} & $\begin{array}{l}20-34 \\
35-64\end{array}$ & $\begin{array}{r}44 \\
147\end{array}$ & $\begin{array}{r}35 \\
175\end{array}$ & $\begin{array}{r}28 \\
139\end{array}$ & $\begin{array}{r}30 \\
124\end{array}$ & $\begin{array}{r}62 \\
130\end{array}$ & $\begin{array}{r}79 \\
161\end{array}$ & $\begin{array}{r}10 \\
106\end{array}$ & $\begin{array}{r}7 \\
67\end{array}$ & $\begin{array}{l}21 \\
41\end{array}$ & $\begin{array}{l}14 \\
36\end{array}$ \\
\hline & & & & $20-64$ & 191 & 210 & 167 & 154 & 192 & 240 & 116 & 74 & 62 & 50 \\
\hline All diseases & 5. & . & . & $20-64$ & 446 & 427 & 324 & 319 & 436 & 530 & 200 & 140 & 119 & 108 \\
\hline
\end{tabular}

TABLE 4

Period Prevalence and Attack Rate of Respiratory Disease, and Attack Rate of All Diseases Combined, by Group and Department (for Details, see Text)

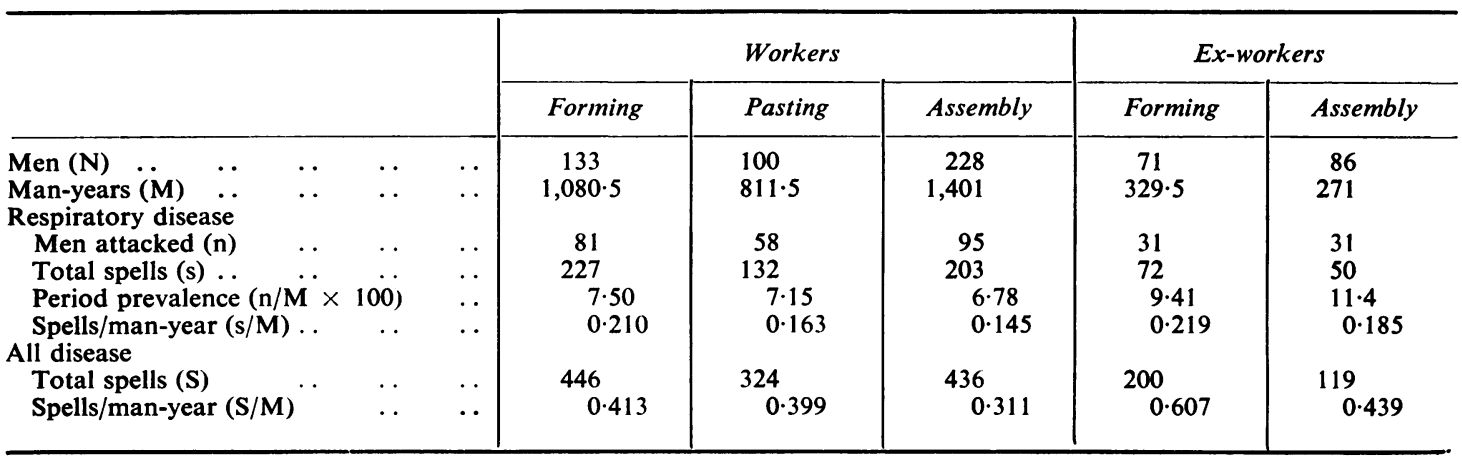


TABLE 5

Decreases in Mean F.E.V.1.0 and Mean F.V.C. (LITRES) DURING THE SHIFT

\begin{tabular}{|c|c|c|c|c|}
\hline & & & Forming & Plate cutting \\
\hline F.E.V.V.1.0 & .. & $\begin{array}{l}\text { Monday } \\
\text { Friday }\end{array}$ & $\begin{array}{l}0 \cdot 16^{1} \\
0 \cdot 16^{1}\end{array}$ & $\begin{array}{l}0 \cdot 07 \\
0 \cdot 12^{1}\end{array}$ \\
\hline F.V.C. .. & .. & $\begin{array}{l}\text { Monday } \\
\text { Friday }\end{array}$ & $\begin{array}{l}0 \cdot 16^{2} \\
0 \cdot 17^{1}\end{array}$ & $\begin{array}{l}0.04 \\
0.09\end{array}$ \\
\hline
\end{tabular}

${ }_{1} \mathbf{P}<0.01 \quad{ }^{2} \mathrm{P}<0.05$.

one day. In another Forming department, Waller (1962) found a mean concentration of $2.7 \mathrm{mg} . / \mathrm{m}^{3}$ with a mass median diameter of $14 \mu$, and $4 \%$ by mass were less than $4 \mu$ diameter. Since sulphuric acid is hygroscopic, the particle size may become larger still during inhalation. Thus, although the concentration of acid mist in this Forming department was sufficient to cause considerable erosion of the teeth and exceeded the threshold limit value of $1 \mathrm{mg} . / \mathrm{m}^{3}{ }^{3}$ (American Conference of Governmental Industrial Hygienists, 1968), the absence of any considerable lower respiratory tract disease might be due to large particle size.

\section{Sickness absence}

The number of spells of sickness absence per manyear (Table 4) in 'workers' varied from 0.31 in Assembly to 0.41 in Forming. Similar rates have been found in bus drivers and conductors (London Transport Executive, 1956) and in the rubber industry (Rubber Manufacturing Employers' Association, 1966), and somewhat higher rates, about $0 \cdot 65$, in an oil refinery (Taylor, 1967).

The rates in 'ex-workers', 0.44 in Assembly and 0.61 in Forming, are higher than in 'workers'. Similar findings in other industries were reported by Buzzard and Shaw (1952) and Taylor (1967).

In the individual disease classes there is an excess of spells of respiratory disease, especially bronchitis, in Forming, and a deficiency in Assembly, although the prevalence of respiratory disease differs little between the two departments. An excess of spells in Forming was not found for other diseases. It therefore seems likely that there are one or more factors present in Forming which are specifically associated with bronchitis and other respiratory disease in susceptible individuals. This is confirmed by the clinical impression made by four men who were transferred from the Forming to other departments in 1963 on account of lower respiratory tract disease. Two of the men, who had been employed less than two years, had no further attacks during the next five years. The attack rates of the other two dropped from 1.4 per year over five years to 0.8 per year over five years, and from 2.0 per year over two years to
0.6 per year over five years.

Since the men in the Forming department were working in 'outdoor' conditions as well as in sulphuric acid mist, it is conceivable that the present findings were due to ill-defined factors known to be present in industrial Lancashire (Fairbairn and Reid, 1958). But taken in conjunction with the findings of Sim and Pattle (1957) described previously, it seems more likely that there is individual respiratory susceptibility to sulphuric acid mist.

\section{Ventilatory capacity}

The statistically significant decreases in mean F.E.V.1.0 and F.V.C. during the shift (Table 5) might be attributed to circadian variation. In their investigation of circadian variation of ventilatory capacity in shift workers, Guberan, Williams, Walford, and Smith (1969) found mean falls of some 0.05 litre in both F.E.V.1.0 and F.V.C. during the afternoon (2 p.m.-10 p.m.) shift.

Amdur et al. (1952) found that the inhalation of sulphuric acid mist by human subjects for 15 minutes produced falls in expiratory and inspiratory flow rates over the first few minutes of exposure but that these returned to normal within 3 minutes of the end of exposure. The absence of statistically significant differences in F.E.V.1.0 and F.V.C. between the Forming men and the Plate Cutting controls could be due to the time of several minutes which elapsed between exposure to acid mist in Forming and observations of ventilatory capacity in the Medical department.

\section{Summary and conclusions}

Compared with control groups, men exposed to high concentrations of sulphuric acid mist in a Forming department had a slight excess of spells of respiratory disease, particularly bronchitis, but not of other disease. There was an increased number of spells in attacked men rather than an increased proportion of men attacked. The absence of a marked excess of lower respiratory tract disease might be due to large mist particle size.

Tests of change of ventilatory capacity during the afternoon shift on a Monday and Friday in Forming men did not differ significantly from those in a control group. The results of both groups were consistent with the known circadian variation.

It will be of interest to determine whether tooth erosion and the excess of spells of respiratory disease are eliminated by the installation of local exhaust ventilation.

I am very grateful to Dr. D. Malcolm for suggesting this investigation and to the Directors of Electric Power Storage Ltd. for permission to undertake it; to Mrs. B. Roughley and the Personnel Department for much clerical assistance; to Miss I. Dingwall-Fordyce and 
Mr. M. K. Molyneux for help with the spirometry; to Miss Joan Walford and Miss Rosemary Wood for statistical assistance; and to Dr. G. A. Rose for advice.

\section{References}

Amdur, M. O. (1961). Report on tentative ambient air standards for sulfur dioxide and sulfuric acid. Ann. occup. Hyg., 3, 71-83. , Silverman, L., and Drinker, P. (1952). Inhalation of sulfuric acid mist by human subjects. Arch. industr. Hyg., 6, 305-313.

American Conference of Governmental Industrial Hygienists (1968). Threshold Limit Values for 1968. 1014, Broadway, Cincinnati, Ohio 45202 .

Anfield, B. D., and Warner, C. G. (1968). A study of industrial mists containing sulphuric acid. Ann. occup. Hyg., 11, 185-194.

Buzzard, R. B., and Shaw, W. J. (1952). An analysis of absence under a scheme of paid sick leave. Brit. J. industr. Med., 9, 282-295.

Fairbairn, A. S., and Reid, D. D. (1958). Air pollution and other local factors in respiratory disease. Brit. J. prev. soc. Med., 12, 94-103.

Goldman, A., and Hill, W. T. (1953). Chronic bronchopulmonary disease due to inhalation of sulfuric acid fumes. Arch. industr. Hyg., 8, 205-211.
Guberan, E., Williams, M. K., Walford, Joan, and Smith, Margaret M. (1969). Circadian variation of F.E.V. in shift workers. Brit. $J$. industr. Med., 26, 121-125.

Haggard, H. W. (1924). Action of irritant gases upon the respiratory tract. J. industr. Hyg., 5, 390-398.

London Transport Executive. (1956). Health in Industry, pp. 32-62. Butterworth, London.

Malcolm, D., and Paul, E. (1961). Erosion of the teeth due to sulphuric acid in the battery industry. Brit. J. industr. Med., 18, 63-69.

McKerrow, C. B., McDermott, M., and Gilson, J. C. (1960). A spirometer for measuring the forced expiratory volume with a simple calibrating device. Lancet, 1, 149-151.

Rubber Manufacturing Employers' Association (1966). Health in the Rubber Industry, a Pilot Study. Manchester.

Sim, V. M., and Pattle, R. E. (1957). Effect of possible smog irritants on human subjects. J. Amer. med. Ass., 165, 1908-13.

Taylor, P. J. (1967). Individual variations in sickness absence. Brit. J. industr. Med., 24, 169-177.

Ten Bruggen Cate, H. J. (1968). Dental erosion in industry. Ibid., 25, 249-266.

Waller, R. E. (1962). Personal communication.

World Health Organization (1967). Manual of The International Statistical Classification of Diseases, Injuries, and Causes of Death. W.H.O., Geneva, 1967. Vol. 1.

Received for publication May 6, 1969 